\title{
The Choice of Foreign-Market Investment Modes: An Empirical Analysis Using Transaction-Cost and Organizational Learning Frameworks
}

\author{
Thanh Tu Phan ${ }^{1} \&$ Manh Chiên $\mathrm{Vu}^{2}$ \\ ${ }^{1}$ Hai Duong University of Economics and Technology \& HKT Consultant, Vietnam \\ ${ }^{2}$ Vietnam Commercial University, Vietnam \\ Correspondence: Manh Chien Vu, Vietnam Commercial University, Ho Tung Mau Street, Hanoi, Vietnam. Tel: \\ 84-9-1320-3945. E-mail: vmchien@yahoo.com
}

Received: June 4, 2012

Accepted: July 10, 2012

Published: August 1, 2012

doi: $10.5539 /$ ijbm.v7n15p14

URL: http://dx.doi.org/10.5539/ijbm.v7n15p14

\begin{abstract}
In this study, we explain the foreign firm's investment mode choice between international joint-venture (IJV) and wholly owned subsidiary (WOS) by analyzing its intrinsic characteristics related to its assets contributed and experiences on host country and the uncertainty of the local environment. Based on the logit regressions of 6603 investment mode decisions made by 5802 foreign investors in Vietnam during 1988 - 2008, our findings were consistent with transaction-cost and organizational learning frameworks. We find positive associations between highly specific assets and the stock of experience of foreign firms with their choice of WOS; so negative ones with their choice of IJV as investment mode. Also, the IJV would be selected in a highly uncertain context; but in a favorable one, the WOS is preferred by the foreign firm.
\end{abstract}

Keywords: international joint-venture, wholly owned subsidiary, entry mode, transaction-cost economics, organizational learning, Vietnam

\section{Introduction}

Increasingly, Foreign Direct Investment (FDI) has become an efficient strategy for firm to invest abroad, enter new markets. Over the last decades, scholars have contributed their researches by providing a rich literature on the investment mode choice of the foreign firm in a host country. Some stated that firms try to establish an internationalization strategy or to reduce competition, while others indicated that firms are motivated by acquiring, exploiting resources or minimizing costs (Anderson and Gatignon, 1986; Hennart, 1988; Tsang, 2000, Brouthers et al., 2003).

In the international literature, Foreign Direct Investments (FDI) imply that (1) the foreign firm will be physically present in the local country by establishing here a new subsidiary which belongs partially or totally to him, and (2) a significant level of its commitment in term of investment to the subsidiary situated in the host country. FDI concerns two principal entry modes of International Joint-venture (IJV) and Wholly Owned Subsidiary (WOS). By definition, "a joint venture occurs when two or more firms pool a portion of their resources within a common legal organization" (Kogut, 1988, p.319). One special characteristic of joint venture is that it has several parents with their own identity who own capital jointly and share its control (Contractor and Lorange, 1988; Hennart, 1988; Inkpen and Beamish, 1997). On the other hand, a Wholly Owned Subsidiary (WOS) is a subsidiary which belongs totally to a single foreign firm. It represents the residual economic and cultural values of its parent firm. Moreover, the foreign parent firm can impose its management system and style to the WOS which could contribute positively to the organizational process of problem solving and to the functioning of the subsidiary (Killing, 1983).

In reality, FDI concerns also other investment modes such as BOT (Build - Operate - Transfer), to BTO (Build Transfer - Operate) and BT (Build - Transfer) co-operative contracts. These are not the subject of the current research, because these modes imply a high influence and intervention of the host government that do not allow to foreign firms a sufficient flexibility in sense of market economy (Root, 1987; Gougeon and Gupta, 1998). So, we concentrate, based on Transaction-Costs Economics (Coase, 1937; Williamson, 1975, 1979) and 
Organizational Learning theory (Yelle, 1979; Levitt and March, 1988; Argote et al., 1990; Hamel, 1991), to analyze the foreign firm's investment mode choice between IJV and WOS.

The aim of this study is, firstly, to constitute a framework for firm's investment mode choice by combining two relevant theoretical approaches of transaction-costs economics and organizational leering theory. Secondly, we wish to expand the geographical research champ of investment mode choice to other countries for exploring new circumstances such as in Vietnam. Thirdly, we will empirically test the framework established in the context of FDI in this country.

This paper is organized into third sections. In the first section, we will develop the theoretical framework and research hypotheses. The second section concerns the research methodology including variable measurement and regression method. Finally, the research results and discussions will be represented in the third section.

\section{Theoretical Background and Hypotheses}

The Transaction-Costs Economics (TCE) approaches the firm in terms of transactions costs, defined as the costs of running the economic system. In the international literature, the Transaction-Costs Economic is a dominant theory which justifies the choice made by a firm abroad according to transaction frequency and asset specificity in an uncertain and opportunism context of the foreign investment country (Kogut, 1988; Hennart, 1988; Tsang, 2000). When a company decides to go to abroad, several entry modes are available, as exporting, co-operative contracts (licensing, franchising, sub-contracting...), international joint venture (IJV) and Wholly Owned Subsidiary (WOS) which correspond respectively to market, hybrid forms and hierarchy. Exporting and co-operative contracts are used when assets are not specific and when the frequency of transactions is occasional. These modes are not the case of FDI where foreign firms look for a regular business in the local country; they are also ready to commit here a non-negligible investment. We now focus on their choice between two FDI modes of IVJ and WOS by analyzing the three most relevant transactional factors: asset specificity, uncertainty and opportunism problem.

\subsection{Asset Specificity and Preference of WOS}

Asset specificity is negatively associated to the possibility of redeployment of theses physical and human assets, which are specialized and unique to an investment. It refers to the degree to which an asset can be redeployed to alternative uses and by alternative users without sacrifice of productive value (Williamson, 1975). A number of studies support that the specificity of assets invested by foreign investor gives it the competitive advantages in the local market, which contribute to improve the subsidiary's performance (Barney, 1991; Isobe et al., 2000). Consequently, a high level of control such as WOS is favoured when the assets are idiosyncratic (Williamson, 1979), i.e. new technologies or intangible resources. The advantage of this investment mode is that the firm does not need to share the profits; totally control the management of the foreign subsidiary; and reduce the risk of unwanted dissemination (Beamish and Banks, 1987; Delios and Henisz, 2000). In other words, the WOS gives the parent firm the "free-riding" to trade with its own rules in the local market ( $\mathrm{Lu}$ and Hébert, 2005); adaptations can be also made sequentially without consulting, adjusting or revising inter-firm agreements (Williamson, 1975). On the other hand, IJV should be selected when the asset specificity is mixed (Williamson, 1979). This form allows firm to "have stronger incentives and adaptive capabilities than hierarchies, while providing more administrative control than markets" (Tsang, 2000, p. 220).

Consequently, we suppose the first hypothesis as follow:

H1a: The greater the degree of specificity of assets invested, the more likely the foreign firm chooses WOS as investment mode.

$\underline{\text { H1b}}$ : The lower the degree of specificity of assets invested, the more likely the foreign firm chooses IJV as investment mode.

\subsection{Uncertainty and Investment Mode Choice}

The second important factor is the uncertainty concerning the environmental changes which cannot be predicted or controlled by foreign investors. There are two types which has different effects on firm's investment abroad (Anderson and Gatignon, 1986). External uncertainty results from volatility in the local environment, it often depends on the political situation of the host country. Internal uncertainty concerns the complexity and the tacit characteristic of the international unit's functioning. It results from an insufficient knowledge or experience of local market such as socio-cultural factors, the language, local customers' habits and suppliers' network. Changes in environmental and business conditions may cause serious problems for the subsidiary including dysfunction, loss and in extreme cases, expropriation of assets (Agarwal and Ramaswami, 1992; Delios and Henisz, 2000). 
In order to mitigate uncertainty's impact, it is recommended that investor firm maintain a certain degree of flexibility and avoid high commitment in the investment (Williamson, 1975). So, face to a high level of uncertainty, firms should avoid high levels of ownership by adopting a mediate and flexible government form such as JVI that require a limited commitment. On the contrary, under a low uncertainty situation, more hierarchical form such as WOS often is preferred by the foreign firm (Williamson, 1975; Anderson and Gatignon, 1986).

In practice, the country investment conditions have a great impact on the foreign firm's internationalization process. This legislative framework is then applied by shaping the "provincial investment conditions" which imply also transaction costs (North, 1990) and influence the foreign firm's choice of investment mode. Meyer and Nguyen (2005) observe that foreign firm prefers the area where provincial institutions encourage their transactions. Recently, Phan's study (2012) indicates clearly that foreign investors prefer great cities and industrial zones in Vietnam. This preference could be explained by two major reasons. First, industrial zones are always encouraged by the local government's favourable legislations (such as reductions and exemptions of taxes, of import-export duties). Second, areas having a great number of FDI are usually more populated and more developed ones, not only economically, with better qualified manpower but also with a better infrastructure.

Consequently, we formulate the second hypothesis on the positive relationship between the uncertainty of host country and the IJV choice of foreign firm:

H2a: In low uncertainty context of host country, foreign firm will tend to prefer WOS as investment mode.

H2b: In high uncertainty context of host country, foreign firm will tend to prefer IJV as investment mode.

\subsection{Experience versus Behavior of the Firm}

For a better understanding of opportunism problem(Note 1) - one of the most significant transactional contingencies faced by foreign firms in strategic alliances such as IJV (Beamish et Banks, 1987), we mobilize organizational learning theory in order to explain the foreign firm' investment mode choice in emerging economies. Organizational learning theory, in the original production context, suggests an improvement of the organization's performance through their process of experience accumulation (Yelle, 1979; Levitt and March, 1988; Argote et al., 1990; Epple et al., 1991).

In the international business field, scholars have found that foreign firm has little experience of the host country environment; it must face off some involvements caused by this lack of knowledge and understanding about host country (Johanson and Wiedersheim-Paul, 1975; Johanson and Vahlne, 1977). So, the foreign firm should favour a non-hierarchy government form such as cooperative contracts or IJV, in order to minimize the investment uncertainty. During time, foreign firm gains confidence and becomes more aggressive in this nondomestic market; his behaviour could be changed in favour of a more hierarchical government form such as WOS: the more rapidly a firm learns, the more likely it will look for a more hierarchical government mode such as WOS (Anderson and Gatignon, 1986; Hamel, 1991; Inkpen, 1998; Phan, 2012). Because, on one hand, the investment uncertainty was reduced, and on another hand, WOS gives to parent firm the possibilities to obtain the total control of this foreign subsidiary and maximizing its profits (Blodgett, 1992; Reuer and Koza, 2000; Lu and Hebert, 2005).

Learning is in fact an essential form of acquiring organizational knowledge. In the case of our current research, this acquisition form gives the opportunity for foreign investors to gain knowledge including local markets, clients, distribution systems, marketing, relations with clients, suppliers and local authorities (Gomes-Casseres, 1987; Inkpen and Beamish, 1997). Once the local environment becomes more familiar to the foreign firm, specifically when foreign firm have acquired enough local knowledge; its initial inconvenient can be minimized; it may move its investment to a more hierarchical government form such as WOS in the host country. Gomes-Casseres's study (1987) support the conclusion of the pioneer Franko (1971) that foreign firm having less experiences in host country chooses IJV as mean facilitating its entry, and then transform their IJV into WOS when it becomes more experienced.

In this line of learning theory, we formulate the third hypothesis:

H3a: The more experienced a foreign firm in host country, the more likely it favours WOS as investment mode. H3b: The less experienced a foreign firm in host country, the more likely it favours IJV as investment mode. 


\section{Methodology}

\subsection{Research Field and Data Collection}

Based on the deductive approach, we will test the four research hypothesis proposed by an empirical study of European firms investing in Vietnam - "an emerging tiger in Asia". This country represents some relevant characteristics to our current research. First, existing empirical studies concentrate mostly on developed countries or developing countries where the market economy is established (Tsang et al., 2004). It is necessary to expand the geographical research champ to other countries by generalizing results obtained and for exploring new circumstances. Secondly, the transition process of Vietnam, after the fall of the socialist regime, was developed with specific endogenous elements which were different from East European countries' ones (Nguyen, 2003) with an out-of-date level of technologies; weak managerial capacity and education criticized for being away from practice. Thirdly, Vietnam is continuing a process developing into an industrialized country, which was initiated by the famous reform "Đổi Mới" in 1986. Foreign investors have to face various problems coming from all internal and external aspects of subsidiary such as the local legal system, fast changes of local legislations, lack of local knowledge, cultural distance between Vietnamese and western managers etc. (Lai and Truong, 2005). These elements discussed above motivate us to choose Vietnam as research field of this study.

Data was collected from FIA (Foreign Investment Agency) - a government agency belonging to the Ministry of Planning and Investment which controls FDIs in Vietnam. From 1988 to 2008, a database recording 6223 investments by foreign firms in Vietnam was compiled. The data was completed by various sources of information including an Internet survey and professional journals. 6223 direct investments recorded in the database correspond to 6603 investment mode decisions made by 5802 foreign investors in Vietnam.

\subsection{Variable Measurement}

\subsubsection{Dependent Variables}

In the current research, the foreign firm's choice of an investment mode in Vietnam is dependent variable; so we have two dependent variables which were encoded by a binary system. For the first variable in WOS choice model, value 0 is distributed to foreign firm's WOS decision; and value 1 is distributed to its IJV choice. In contrast, for the second in IJV choice model, value 0 is distributed to foreign firm's IJV decision; and value 1 is distributed to its WOS choice. The binary variable is represented as follow:

$$
\boldsymbol{y}_{i}=\left\{\begin{array}{c}
1 \text { if the investment is target investment mode } \quad \forall \mathrm{i} \in[1, \mathrm{~N}=6603] \\
0 \text { if the investment is not target investment mode }
\end{array}\right.
$$

\subsubsection{Independent Variables}

Asset specificity: In agreement with Delios and Henisz (2000), Chen and Hennart (2002), the resource value is associated with the subsidiary's R\&D. The ratio of R\&D and the total turnover generated by the subsidiary is used to measure the specificity of assets.

Uncertainty: Uncertainty is measured by Vietnam political risk for the year when the investment decision is made. This risk provided by the Political Risk Services(Note 2) that allows us to measure the environmental stability of this country. In order to facilitate the interpretation, we have inverted the RPS's scale; consequently, the higher the political risk score, the worse uncertainty and vice versa.

Foreign firm's experiences of the host country: as scholars in the literature (Hennart et al., 1998; Delios and Beamish, 2001; Lu and Hebert, 2005; Lowen and Pope, 2008), we measured this variable by the number of years spent by the foreign firm in Vietnam until the targeted investment decision.

Provincial legal support: We coded this variable as an ordinal variable that has been distributed to 2 if the foreign investment is found in the economically difficult areas; to 1 for industrial and economic areas; 0 if the investment is found in other regions of Vietnam.

Economic Conditions in the Provinces: This ordinal qualitative variable is coded in four modalities: the value of 3 was distributed for Hanoi and Ho Chi Minh City - the special cities; 2 for cities in first class (10 provinces); 1 for cities in second class (12 provinces); 0 is for the rest of the country(Note 3).

\subsubsection{Control Variables}

Amount of investment is the legal capital of subsidiary in Vietnam. This variable is in USD converted in a logarithmic value.

Cultural distance between the investor's country of origin and Vietnam: this value is usually calculated 
according to Kogut and Singh (1988), and then used by a number of authors (Luo, 2006; Lowen and Pope, 2008; Meschi and Riccio, 2008). It is a deviation of four cultural references (Hofstede, 1980: power distance, individualism, masculinity and uncertainty avoidance) (Note 4) of the foreign investor's country of origin compared with Vietnam. The deviations are then corrected by dividing its square values by the deviance of each cultural dimension.

Size of the foreign company: This variable was coded in 1 for foreign companies giving no information on their turnover or between 0 and 20 million dollars; in 2 for a turnover between 20 and 200 million dollars; in 3 for a turnover between 200 and 400 million dollars; and in 4 for a turnover more than 400 million dollars.

\subsubsection{Logistic Regression Model}

Logistic regression is a method using a qualitative binary value, which can only have two values: 1 and 2 (Agresti, 2007) such as our dependent variable. The logistic or logit function allows to transform an S shaped curve into a straight line, which modifies also the variable interval from $[0 ; 1]$ to $[-\infty ;+\infty]$. It is defined by the natural logarithm $(\ln )$ of the odds of firm's choice:

$$
\operatorname{logit}(p)=\ln \frac{p}{1-p}
$$

where $\mathrm{p}$ is the probability of the choice of an investment mode.

With this transformation, the relationship between the probability of the investor's choice and independent variables becomes a linear function as follows:

$$
\operatorname{logit}(\mathrm{p})=\mathrm{a} 0+\mathrm{ai}{ }^{*} \mathrm{xi}+\varepsilon \quad(\mathrm{i}=1, \ldots, 8)
$$

where logit (p) is the natural logarithm $(\ln )$ of the odds values of the investor's choice

$$
\begin{aligned}
& \text { a: estimated coefficients } \\
& \mathrm{x}_{\mathrm{i}} \text { : independent and control variables } \\
& \varepsilon \text { : error term }
\end{aligned}
$$

Based on this equation, we have verified the research hypotheses, in using the Stata software. Initially, table 1 represents the descriptive analysis and collinearity diagnostics of independent variables. The collinearity of independent variables is evaluated by its tolerance and VIF (Variance Inflation Factor) values. A small tolerance value of a variable indicates its perfect linear combination with other variables already included in the regression model; and this variable must be removed from the logistic regression. The VIF value $(=1 /$ tolerance) measures the collinearity impact of independent variables on the regression model. VIF values which are superior to 2.5 indicate a collinearity problem (Baum, 2006). In the current research, all of VIF values are less than 2.5 which mean that the collinearity risks in the regression model are not significant.

Table 1. Diagnostics of independent variables

\begin{tabular}{lcccccc}
\hline \multirow{2}{*}{ Independent variable } & \multicolumn{3}{c}{ Descriptive statistics } & \multicolumn{2}{c}{ Collinearity } \\
\cline { 2 - 6 } & Min & Max & Average & $\begin{array}{c}\text { Standard } \\
\text { deviation }\end{array}$ & VIF & Tolerance \\
\hline Asset specificity & 0 & 24.6 & 0.991 & 1.582 & 1.02 & 0.9778 \\
Uncertainty & 46 & 72 & 66.116 & 5.012 & 1.03 & 0.9667 \\
Provincial legal support & 0 & 2 & 0.994 & 0.263 & 1.01 & 0.9874 \\
Provincial economic conditions & 0 & 3 & 1.637 & 1.292 & 1.07 & 0.9355 \\
Experiences & 0 & 19 & 1.549 & 2.080 & 1.03 & 0.9755 \\
Investment Amount & 0 & 8.903 & 6.032 & 0.831 & 1.03 & 0.9723 \\
Cultural distance & 0.213 & 4.783 & 1.722 & 1.364 & 1.05 & 0.9512 \\
Size & 1 & 4 & 1.693 & 1.026 & 1.06 & 0.9428 \\
\hline
\end{tabular}

Then, an analysis of correlation matrix is carried out in table 2. Each value indicates how two variables are associated. The values close to -1 or +1 show a strong linear relationship (more than 0.7 or less than -0.7 
indicates a strong association). A value equal to 0 means that two variables are completely independent from each other (Baum, 2006). As the collinearity diagnostic results, the correlation coefficients of independent variables were around of 0 (see table 2): the minimum coefficient between external uncertainty and the investing company size is -0.161 ; the maximum coefficient between experiences and company size and between provincial legal support and provincial economic conditions is 0.143 . These results confirm that the collinearity risk is minimized in our logistic regression.

Table 2. Correlation matrix of independent variables

\begin{tabular}{lcccccccc}
\hline Independent variable & $(1)$ & $(2)$ & $(3)$ & $(4)$ & $(5)$ & $(6)$ & $(7)$ & $(8)$ \\
\hline Asset specificity & 1 & & & & & & & \\
Uncertainty & 0.016 & 1 & & & & & \\
Provincial legal support & $0.021^{*}$ & $-0.027^{*}$ & 1 & & & & & \\
Provincial eco. conditions & $-0.072^{* * *}$ & $-0.122^{* * *}$ & $0.101^{* * *}$ & 1 & & & & \\
Experiences & $-0.025^{* *}$ & $0.074^{* * *}$ & 0.015 & -0.011 & 1 & & \\
Investment Amount & -0.004 & -0.011 & 0.007 & $-0.110^{* * *}$ & $0.061^{* * *}$ & 1 & & \\
Cultural distance & $0.101^{* * *}$ & $0.064^{* * *}$ & -0.002 & $0.116^{* * *}$ & $0.035^{* *}$ & 0.011 & 1 & \\
Size & $0.059^{* * *}$ & $0.088^{* * *}$ & -0.014 & $0.055^{* * *}$ & $0.128^{* * *}$ & $0.099^{* * *}$ & $0.148^{* * *}$ & 1 \\
\hline
\end{tabular}

\section{Results and Analysis}

\subsection{Research Results}

The table 3 shows the final results of the logic regression. Model 1 corresponds to scenario where IJV as target entry mode is coded in 1 , WOS in 0 ; model 2 corresponds to scenario where WOS as target entry mode is coded in 1, JVI in 0 . In these logistic regressions; the Wald test is used to verify the significance of each estimated coefficient. By using the Chi-squared test, we assess the quality of the adjustment and specifications of the regression models. According to regression results, these tests in model 1 and 2 are significant with a maximum confidence level of $99.9 \%(\mathrm{p}<0.001)$. So, the quality of the adjustment and the specification of two regression models are assured.

Table 3. Results of logit regression

\begin{tabular}{|c|c|c|c|c|}
\hline \multirow[t]{2}{*}{ Independent variable } & \multicolumn{2}{|c|}{ Model 1: IJV versus WOS } & \multicolumn{2}{|c|}{ Model 2: WOS versus IJV } \\
\hline & $\begin{array}{r}\text { Coefficient } \\
\text { (Odds Ratio) }\end{array}$ & Std. Err. & $\begin{array}{r}\text { Coefficient } \\
\text { (Odds Ratio) }\end{array}$ & Std. Err. \\
\hline Asset specificity & $-0.274(0.76)^{* * *}$ & 0.020 & $0.274(1.315)^{* * *}$ & 0.020 \\
\hline Uncertainty & $0.094(1.098)^{* * *}$ & 0.006 & $-0.094(0.91)^{* * *}$ & 0.006 \\
\hline Provincial legal support & $-0.216(0.806)^{*}$ & 0.107 & $0.216(1.241)^{*}$ & 0.107 \\
\hline Provincial eco. conditions & $0.296(1.345)^{* * *}$ & 0.022 & $-0.296(0.744)^{* * *}$ & 0.022 \\
\hline Experiences & $-0.048(0.953)^{* * *}$ & 0.014 & $0.048(1.049)^{* * *}$ & 0.014 \\
\hline Investment Amount & $0.633(1.883)^{* * *}$ & 0.039 & $-0.633(0.531)^{* * *}$ & 0.039 \\
\hline Cultural distance & $-0.008(0.992)$ & 0.020 & $0.008(1.008)$ & 0.020 \\
\hline Size & $0.005(1.005)$ & 0.027 & $-0.005(0.995)$ & 0.027 \\
\hline cons & 2.025 & 0.481 & -2.025 & 0.481 \\
\hline \multicolumn{5}{|l|}{ Goodness of Fit Test } \\
\hline Observation number & 6603 & & 6603 & \\
\hline LR Chi-Square test & $1016.82 * * *$ & & $1016.82 * * *$ & \\
\hline
\end{tabular}


We verify now the validity of proposed hypotheses. Concerning the hypotheses 1 , we have proposed that: (H1a) for highly specific assets, the foreign firm selects a more hierarchical investment mode such as WOS; on the contrary, for a mixt degree of asset specificity, IJV is often preferred. The estimated coefficients of this variable are -0.274 for IJV in model 1 and 0.274 for WOS in model 2; the Wald tests are significant at confident level of $95 \%(\mathrm{p}<0.05)$. This indicates a negative association between the foreign firm's asset specificity and their choice of IJV; and a positive association with their WOS choice. The odds values of 0.76 for IJV model 1 and 1.315 for WOS model 2 mean that: when the asset specificity increases by 1 unit (or the intensity of R\&D increases of $1 \%$ ); the probability for foreign firm to choose IJV as investment mode decreases by $24 \%$ ( $=1-0.76$ odd value); but increases by $31.5 \%$ (= 1.315 odd value -1$)$ for their WOS choice. So the hypotheses $1 \mathrm{a}$ and $1 \mathrm{~b}$ are confirmed.

These results are consistent with the ones of scholars in the literature. Delios and Beamish (1999), analyzing a sample of 1424 Japanese firms investing in Asia, indicate positive and significant impacts of asset specificity (measured by advertising incentives and research and development incentives) on the level of ownership of Japanese firms. Tsai and Cheng (2004), revising the entry mode strategy of Taiwanese firms in China, in South-East Asia and in Eastern Europe, observe also the WOS preference of Taiwanese investors.

Hypotheses 2 concern the positive relationship between uncertainty and the firm's IJV choice, but negative one for their WOS choice as entry mode. The estimated coefficients in regression models 1 and 2 are respectively positive and negative with significant Wald tests at $99.9 \%$ confident level $(\mathrm{p}<0.001)$. These results imply that: the higher the uncertainty, the more likely the foreign firm selects IJV, the less likely it selects WOS as investment mode. Specifically, when uncertainty or political risk increase by 1 unit, the probability of IJV choice will increase by $9.8 \%$ (= 1.098 odd value -1$)$, the one of WOS choice will decrease by $9 \%$ (= $1-0.91$ odd value) We can so validate these hypotheses $\mathrm{H} 2 \mathrm{a}$ and $\mathrm{H} 2 \mathrm{~b}$. These findings support empirical studies in the literature: IJV are an attractive alternative in high-uncertainty context where foreign firms should maintain the necessary flexibility due to unpredicted changes in the environment (Anderson and Gatignon, 1986; Agarwal and Ramaswami, 1992; Erramilli and Rao, 1993; Zhao et al., 2004).

An extended analysis considers the impact of the provincial legal and economic conditions on the investor's entry mode decision. All of the Wald tests for these two variables give significant results at $95 \%$ confident level $(p<0.05)$ in two regression models. The estimated coefficients indicate a negative relationship of provincial legal support with firm's IJV choice (-0.216 in model 1); but a positive one with its WOS choice (-0.216 in model 1). These relationships are inversed for the provincial economic conditions: a positive one for IJV (0.296 in model 1) and a negative one for WOS (-0.296 in model 1). These results imply that: WOS is preferred in area having favourable legal and economic conditions; and in more legally and economically difficult area, it is more likely that foreign firm will choose IJV as investment mode.

Our findings supported ones of Meyer and Nguyen (2005) and Phan (2012) who observe that foreign firms like the area where provincial institutions encourage their transactions. This preference could be explained by two major reasons. First, industrial zones are always encouraged by the local government's favourable legislations (such as reductions and exemptions of taxes, of import-export duties). Second, areas having a great number of FDI are usually more populated and more developed ones, not only economically, with better qualified manpower but also with a better infrastructure. Consequently, we can confirm that the institutional and economic conditions at both provincial and national levels have significant impact on foreign firm's investment mode choice: favourable investment conditions encourage the foreign firms' WOS choice; and in less favourable context, IJV is preferred for sharing investment uncertainty.

Concerning the hypotheses 3 , we have proposed that the more experienced the foreign firm, the more likely it will choose the more hierarchical governance mode such as WOS (H3a); but the less experienced the foreign firm, the more likely it will choose IJV as investment mode (H3b). The obtained results confirm our hypotheses 3. The estimated coefficients of -0.048 in model 1 and of 0.048 in model 2 are significant at $99.9 \%$ confident level $(\mathrm{p}<0.001)$; its odds values respectively of 0.953 and of 1.049 indicate a negative association between the foreign firm's experience on host country and his IJV choice and a positive one with his WOS choice: for his each year spent in the host country, the chance for foreign firm to choose a IJV will decrease by $4.7 \%$; the one to choose a WOS as its investment mode will increases by $4.9 \%$.

These results are consistent with Hamel's "learning race" perspective (1991). In practice, a WOS allows the foreign parent firm to obtain a complete control (Blodgett, 1992; Reuer and Koza, 2000), which can (1) reduce the risk of conflict in the decision-making processes of the subsidiary (Killing, 1983; Beamish, 1985), (2) secure strategic resources contributed (Luo, 2001), and (3) gain the economies of scope by optimizing national and 
international subsidiary network of parent firm (Gomes-Casseres, 1987; Luo, 2001). Consequently, a foreign firm may not be interested in hybrid forms in which the benefits are shared with other (local) partner (Barkema and Vermeulen, 1998). In his recent empirical study on the IJV population in Vietnam, Phan (2012) observes also that the more experienced the foreign partner in the host country, the more likely the foreign parent internalize IJV by transforming it into WOS.

Looking at control variables, in our logistic regression models, only the estimated coefficients of investment amount variable are significant at $95 \%$ confident level $(p<0.05)$. This means that in the important investment, foreign firm prefer cooperative government mode such as IJV for sharing investment risk. On the contrary, we did not find any impact of foreign firm's size and the cultural distance between host country and foreign firm's one of origin.

\subsection{Discussion}

The findings of the current study were consistent with the Transaction-Costs Economics (Williamson, 1979): asset specificity and the reduction of uncertainty have a positive association with the foreign firm's WOS choice and a negative one with their choice of IJV as government mode. This preference is justified by three basic advantages. Firstly, a WOS allows foreign firm to fully exploit the economic rents generated by its specific assets contributed (Killing, 1983; Harrigan, 1985). Secondly, the dissemination risks of specific assets, which allow firm to obtain competitive advantage, can be minimized in a government mode such as WOS against opportunistic behavior of other firms (Anderson and Gatignon, 1986; Agarwal and Ramaswani, 1992; Errarnilli and Rao, 1993).

These conclusions are also convergent or complementary with the resource-based view (Barney, 1991; Grant, 1991; Kogut and Zander, 1992): Specific resources, which are the source of competitive advantage, allow firm to obtain the quasi-rents which come from the difference between the acquisition value of a resource and the value generated by using or from the imperfect mobility of this resource (property rights, specificity). Profits are maximized only if firm exploit fully and it-self its resources. The dissemination risks linked to resource are also high, particularly when firm decides to invest abroad. This is another reason for the firm to decide to go abroad and to create a WOS. WOS is consequently preferred by foreign firms to other entry modes such as IJV for highly specific assets.

The results confirm also the important role of uncertainty, which is a fundamental factor of Transaction-Costs Economics. We found a significant impact of uncertainty both at national and provincial levels on foreign firm's investment mode decision: the lower the uncertainty, the more likely foreign firm choose WOS as government mode abroad; on the contrary, the higher the uncertainty, the more likely foreign firm choose IJV as investment mode.

Our findings support also other theoretical theories such as transition approach (Franko, 1971; Gomes-Casseres, 1987), the Transaction-Costs Economics (Williamson, 1979) and option theory (Kogut, 1991). The two first approaches consider IJV as a transitional or hybrid mode which facilitate the foreign firm's internationalization process at the beginning; then, the IJV will eventually be transformed into a hierarchical government form such as WOS. The option theory stipulates that if the future growth of IJV is promising (higher than the acquisition cost), it will be acquired by the partner that perceives it with the higher value.

In the same line with organizational learning theory (Hamel, 1991), the results of the current research confirm a positive association between accumulated experience on host country and the foreign firm' WOS preference. This opportunist approach point out that most foreign firms consider its personal interests in detriment of hybrid or cooperative government mode such as IJV. This is the Hamel's "learning race" (1991) in the strategic alliance where the parent firm's learning is successfully achieved; its understanding and experience of local conditions have been improved; it may seek to transform the alliance into WOS.

\section{Conclusion}

This study aims to provide an empirical analysis on the factors that determinate foreign firms' investment mode choice in the context of an emerging country such as Vietnam. Based on transaction-cost and organizational learning approaches, we have found significant associations of foreign firm's asset specificity, experience and environmental uncertainty with its choice between WOS and IJV as investment mode. Specifically, for highly specific assets, firm will be more likely to choose WOS; IJV will be an efficient alternative for a mixt degree of asset specificity. Also, foreign firm having more experiences of host country tend to use WOS to totally control and exploit its subsidiary; but less experienced firm prefers IJV as investment mode for sharing investment risk. In the same line, in high-uncertainty context, IJV will be favored; and in low-uncertainty one, WOS will be more 
efficient government mode abroad.

The current research has some limits, particularly concerning the secondary database and the ignorance of interaction variables during the regression phase. These limits can be considered for future research. Also, it may be interesting to explain the foreign firm's investment mode decision by a deeper analysis combining several theoretical approaches including transaction-costs economics, resource-based view, institutional theory, transitional approach or option theories. Other variables concerning the economic performance, competition, parent firms could be integrated to the regression model in order to better explain the foreign firm's choice.

Our research makes some positive contributions. Its major interest is to discuss a new and promising topic in FDI literature that concerns the current WOS preference tendency of foreign firms in emergent and developing countries such as Vietnam. The findings are particularly in agreement with the transaction-costs economics and with the organizational learning theory. The role of foreign investor's experience for its investment mode decision is also clarified. Furthermore, managerial contributions are important: foreign firm's investment strategy is analyzed in order to encourage their investment, whether they are multinational, local firms or local government. We conclude by pointing out that the foreign firms' investment mode choice is based on their self-interest seeking principle regarding the specificity of its assets contributed to the subsidiary, the uncertainty of local investment environment and its experiences.

\section{References}

Agarwal S., \& Ramaswami S.N. (1992). The choice of foreign market entry mode: impact of ownership, location and internationalization factors. Journal of International Business Studies, 23 (1), p. 1-27. http://dx.doi.org/10.1057/palgrave.jibs.8490257

Agresti A. (2007). An introduction to categorical data analysis (2nd Edition). Wiley-Interscience.

Anderson E., \& Gatignon H. (1986). Modes of foreign entry: a transaction cost analysis and proposition. Journal of International Business Studies, 17, 1-16. http://dx.doi.org/10.1057/palgrave.jibs.8490432

Argote L., Beckman S.L., \& Epple D. (1990). The persistence and transfer of learning in industrial settings. Management Science, 36, 140-154. http://dx.doi.org/10.1287/mnsc.36.2.140

Barkema H.G., \& Vermeulen F. (1998). International expansion through start-up or through acquisition: a learning perspective. Academy of Management Journal, 41, 7-26. http://dx.doi.org/10.2307/256894

Barney J.B. (1991). Firm Resources and Sustained Competitive Advantage. Journal of Management, 17(March), 99-120. http://dx.doi.org/10.1177/014920639101700108

Baum C.F. (2006). An introduction to modern econometrics using Stata. Stata Press Publication.

Beamish P.W. (1985). The characteristics of joint ventures in developed and developing countries. Columbia Journal of World Business, 20, 3-19.

Beamish P.W., \& Banks J.C. (1987). Equity joint ventures and the theory of the multinational enterprise. Journal of International Business Studies, 19(2), 1-16. http://dx.doi.org/10.1057/palgrave.jibs.8490403

Blodgett L. (1992). Factors in the instability of international joint ventures: an event history analysis", Strategic Management Journal, 13(6), 475-481. http://dx.doi.org/10.1002/smj.4250130607

Brouthers K.D., Brouthers L.E., \& Werner S. (2003). Transaction cost enhanced entry mode choices and firm performance. Strategic Management Journal, 24, 1239-1248. http://dx.doi.org/10.1002/smj.362

Chen S.F., \& Henart J.F. (2002). Japanese Investors' Choice of Joint Ventures Versus Wholly Owned Subsidiaries in the US: The Role of Market Barriers and Firm Capabilities. Journal of International Business Studies, 33(1), 1-18. http://dx.doi.org/10.1057/palgrave.jibs.8491002

Coase R.H. (1937). The nature of the firm. Economica, 4, 386-405. http://dx.doi.org/10.1111/j.1468-0335.1937.tb00002.x

Contractor F.J., \& Lorange P. (1988). Cooperative Strategies in International Business. Lexington Books: Lexington, MA.

Delios A., \& Beamish P.W. (1999). Ownership strategies for Japanese firms: Transactional, institutional, and experience influences. Strategic Management Journal, 20(10), 915-933. http://dx.doi.org/10.1002/(SICI)1097-0266(199910)20:10<915::AID-SMJ51>3.0.CO;2-0

Delios A., \& Beamish P.W. (2001). Survival and Profitability: The Roles of Experience and Intangible Assets in Foreign Subsidiary Performance. Academy of Management Journal, 44(5), 1028-1038. 
http://dx.doi.org/10.2139/ssrn.305345

Delios A., \& Henisz W.J. (2000). Japanese firms' investment strategies in emerging economies. Academy of Management Journal, 43, 305-323. http://dx.doi.org/10.2139/ssrn.305342

Epple D., Argote L., \& Devadas R. (1991). Organizational learning curves: a method for investigating intra-plant transfer of knowledge acquired through learning by doing. Organization Science, 2(1), 58. http://dx.doi.org/10.1287/orsc.2.1.58

Erramilli M.K., \& Rao C.P. (1993). Service Firms' Choice of Foreign-Market Entry Modes: An Empirical Analysis Using a Modified Transaction-Cost Framework. Journal of Marketing, 57(July), 19-38. http://dx.doi.org/10.1016/0148-2963(92)90024-6

Franko L.G. (1971). Joint Venture Survival in Multinational Corporations. Praeger: New York.

Gomes-Casseres B. (1987). Joint Venture Instability: Is it a Problem?. Columbia Journal of World. Business, Summer, 97-102.

Grant R.M. (1991). The resource-based theory of competitive advantage: Implications for strategy formulation. California Management Review, 33(3), 114-135. http://dx.doi.org/10.1016/B978-0-7506-7088-3.50004-8

Hamel G. (1991). Competition for competence and inter partner learning within international strategic alliances. Strategic Management Journal, 12(S1), 83-103. http://dx.doi.org/10.1002/smj.4250120908

Harrigan K.R. (1985). Strategies for Joint Ventures. Lexington Books: Lexington, MA.

Hennart J.F. (1988). A transaction cost theory of equity joint ventures. Strategic Management Journal, 9(4), 361-374. http://dx.doi.org/10.1002/smj.4250090406

Hennart J.F., Kim D., \& Zeng M. (1998). The impact of joint venture status on the longevity of Japanese stakes in U.S. manufacturing affiliates. Organization Science, 9, 382-395. http://dx.doi.org/10.1287/orsc.9.3.382

Hofstede G. (1980). Culture's Consequence: International Differences in Work-related Values. Sage: Beverly Hills, CA.

Inkpen A.C. (1998). Learning and knowledge acquisition through international strategic alliances. Academy of Management Executive, 12(4), 69-80. http://dx.doi.org/10.5465/AME.1998.1333953

Inkpen A.C., \& Beamish P.W. (1997). Knowledge, bargaining power and the instability of international joint venture. Academy of Management Review, 22(1), 177-202. http://dx.doi.org/10.2307/259228

Isobe T., Makino S., \& Montgomery D.B. (2000). Resource Commitment, Entry Timing, and Market Performance of Foreign Direct Investments in Emerging Economies: The Case of Japanese International Joint Ventures in China. Academy of Management Journal, 43(3), 468-484. http://dx.doi.org/10.2307/1556405

Johanson J., \& Vahlne J.E. (1977). The internationalization process of the firm: A model of knowledge development and increasing foreign market commitments. Journal of International Business Studies, 8(Spring-Summer), 23-32. http://dx.doi.org/10.1057/palgrave.jibs.8490676

Johanson J., \& Wiedersheim-Paul F. (1975). The internationalization of the firm - Four Swedish cases. Journal of Management Studies, 12(3), 305-22. http://dx.doi.org/10.1111/j.1467-6486.1975.tb00514.x

Killing J.P. (1983). Strategies for Joint Venture Success. Praeger: New York.

Kogut B. (1988). Joint ventures: theoretical and empirical perspectives. Strategic Management Journal, 9, 319-332. http://dx.doi.org/10.1002/smj.4250090403

Kogut B., \& Singh H. (1988). The effect of national culture on the choice of entry mode. Journal of International Business Studies, 19(Fall), 411-432. http://dx.doi.org/10.1057/palgrave.jibs.8490394

Kogut B., \& Zander U. (1992). Knowledge of the firm, combinative capabilities and the replication of technology. Organization Science, 3, 383-397. http://dx.doi.org/10.1287/orsc.3.3.383

Lai XT., \& Truong Q. (2005). Relational Capital and Performance of International Joint Ventures in Vietnam. Asia Pacific Business Review, 11(3), 389-410. http://dx.doi.org/10.1080/13602380500068532

Levitt B., \& March JG. (1988). Organizational learning. Annual Review of Sociology, 14, 319-340. http://dx.doi.org/10.1146/annurev.soc.14.1.319

Lowen, A., \& Pope, J. (2008). Survival Analysis of International Joint Venture Relationships. Journal of Business \& Economics Studies, 14(1), Spring 2008. http://dx.doi.org/10.1007/s11294-006-9069-4 
Lu JW., \& Hébert L. (2005). Equity control and the survival of international joint ventures: a contingency approach. Journal of Business Research, 58(6), June, 736-745. http://dx.doi.org/10.1016/j.jbusres.2003.08.012

Luo Y. (2001). Toward a cooperative view of MNC-host government relations: building blocks and performance implications. Journal of International Business Studies, 32(3), 401-20. http://dx.doi.org/10.1057/palgrave.jibs.8490974

Luo Y. (2006). Toward the micro- and macro-level consequences of interactional justice in cross-cultural joint ventures. Human Relations, 59(8), 1019-1047. http://dx.doi.org/10.1177/0018726706068769

Meschi P.X., \& Riccio E.L. (2008). Country risk, national cultural differences between partners and survival of international joint ventures in Brazil. International Business Review, 17(3), 250-266. http://dx.doi.org/10.1016/j.ibusrev.2007.11.001

Meyer K., \& Nguyen H.V. (2005). Foreign Investment Strategies and Sub-national Institutions in Emerging Markets: Evidence from Vietnam. Journal of Management Studies, 42(1), 63-93. http://dx.doi.org/10.1111/j.1467-6486.2005.00489.x

North D.C. (1990). Institutions, Institutional Change and Economic Development. Cambridge: Cambridge University Press.

Phan T.T. (2012). Survie de la joint-venture internationale: Étude empirique au Vietnam. Editions universitaires européennes.

Reuer J.J., \& Koza M.P. (2000). Asymmetric information and joint venture performance: theory and evidence for domestic and international joint ventures. Strategic Management Journal, 21(1), 81-88. http://dx.doi.org/10.1002/(SICI)1097-0266(200001)21:1<81::AID-SMJ62>3.0.CO;2-R

Tsang E.W.K., Nguyen D.T., \& Erramilli M.K. (2004). Knowledge Acquisition and Performance of International Joint Ventures in the Transition Economy of Vietnam. Journal of International Marketing, 12(2), 82-103. http://dx.doi.org/10.1509/jimk.12.2.82.32901

Tsang E.W.R. (2000). Transaction cost and resource-based explanations of joint ventures: A comparison and synthesis. Organization Studies, 21(1), 215-242. http://dx.doi.org/10.1177/0170840600211004

Williamson O.E. (1975). Markets and Hierarchies: Analysis and Antitrust Implications. The Free Press: New York.

Williamson O.E. (1979). Transaction-Cost Economics: The Governance of Contractual Relations. Journal of Law and Economics, 22, 233-261. http://dx.doi.org/10.1086/466942

Yelle L.E. (1979). The Learning Curve: Historical Review and Comprehensive Survey. Decision Sciences, 10, 302-328. http://dx.doi.org/10.1111/j.1540-5915.1979.tb00026.x

Zhao H., Luo Y., \& Suh T. (2004). Transaction cost determinants and ownership-based entry mode choice: A meta-analytical review. Journal of International Business Studies, 35(6), 524-544. http://dx.doi.org/10.1057/palgrave.jibs. 8400106

\section{Notes}

Note 1. “... opportunism refers to a lack of candor or honesty in transactions, to include self-interest seeking with guile". (Williamson, 1975, p.9).

Note 2. PRS Group's political risk statistics includes: government stability, socioeconomic conditions, investment profile, internal and external conflict, corruption, military in politics, religious tensions, law and order, ethnic tensions, democratic accountability, bureaucracy quality (http://www.prsgroup.com/ICRG_Methodology.aspx.).

Note 3. These areas and cities have been classified according to drastic criteria: economic, political or cultural centers, quality of the infrastructure, population, etc. (decree 42/2009/ND-CP approved on 2/07/2009).

Note 4. For countries where Hofstede's cultural index has not been defined, they were associated with their neighbouring countries (http://www.geert-hofstede.com), for example: Belarus, Slovenia, and Ukraine have been associated with Slovakia, Latvia to Estonia, etc. 